\title{
Seasonal patterns of viral and bacterial infections among children hospitalized with community-acquired pneumonia in a tropical region
}

\author{
CRISTIANA M. NASCIMENTO-CARVALHO ${ }^{1}$, MARIA-REGINA A. CARDOSO $^{2}$, \\ ALDINA BARRAL ${ }^{3}$, CÉSAR A. ARAÚJO-NETO ${ }^{4}$, JULIANA R. OLIVEIRA ${ }^{5}$, \\ LUCIANA S. SOBRAL ${ }^{5}$, ANNIKA SAUKKORIIPI ${ }^{6}$, MIKA PALDANIUS $^{6}$, \\ RAIJA VAINIONPÄ̈̈ ${ }^{7}$, MAIJA LEINONEN ${ }^{6} \&$ OLLI RUUSKANEN $^{8}$
}

From the ${ }^{1}$ Paediatrics Department, Federal University of Bahia School of Medicine, Salvador, ${ }^{2}$ Epidemiology Department, Faculty of Public Health, São Paulo University, São Paulo, ${ }^{3}$ Pathology Department, Federal University of Bahia School of Medicine and Centro de Pesquisa Gonçalo Muniz, Fundação Oswaldo Cruz, Salvador, ${ }^{4}$ Image Diagnosis Department, Federal University of Bahia School of Medicine, Salvador, ${ }^{5}$ Professor Hosannah de Oliveira Paediatric Centre, Federal University of Bahia, Salvador, Brazil, ${ }^{6}$ National Institute for Health and Welfare, Oulu, ${ }^{7}$ Virology Department, and ${ }^{8}$ Paediatrics Department, University of Turku, Turku, Finland

\begin{abstract}
Community-acquired pneumonia (CAP) is a common cause of morbidity among children. Evidence on seasonality, especially on the frequency of viral and bacterial causative agents is scarce; such information may be useful in an era of changing climate conditions worldwide. To analyze the frequency of distinct infections, meteorological indicators and seasons in children hospitalized for CAP in Salvador, Brazil, nasopharyngeal aspirate and blood were collected from 184 patients aged $<5$ y over a 21 -month period. Fourteen microbes were investigated and $144(78 \%)$ cases had the aetiology established. Significant differences were found in air temperature between spring and summer $(p=0.02)$ or winter $(p<0.001)$, summer and fall $(p=0.007)$ or winter $(p<0.001)$, fall and winter $(p=0.002)$, and on precipitation between spring and fall $(p=0.01)$. Correlations were found between: overall viral infections and relative humidity $(p=0.006 ; r=0.6)$ or precipitation ( $p=0.03 ; r=0.5)$, parainfluenza and precipitation $(p=0.02 ; r=-0.5)$, respiratory syncytial virus (RSV) and air temperature $(p=0.048 ; r=-0.4)$ or precipitation $(p=0.045 ; r=0.4)$, adenovirus and precipitation $(p=0.02$; $r=0.5)$, pneumococcus and air temperature $(p=0.04 ; r=-0.4)$, and Chlamydia trachomatis and relative humidity $(p=0.02 ; r=-0.5)$. The frequency of parainfluenza infection was highest during spring $(32.1 \% ; p=0.005)$ and that of RSV infection was highest in the fall $(36.4 \% ; p<0.001)$. Correlations at regular strength were found between several microbes and meteorological indicators. Parainfluenza and RSV presented marked seasonal patterns.
\end{abstract}

\section{Introduction}

Community-acquired pneumonia (CAP) is a common cause of morbidity among children, mostly in those aged under $5 \mathrm{y}$, imposing a heavy burden on health care systems [1]. Currently, about $20 \%$ of the overall child mortality burden is attributable to CAP disease, of which $95 \%$ occurs in developing countries [2]. The clinical presentation is similar for CAP caused by different agents, but the epidemiological impact differs among several causative microbes [3]. Nonetheless, data on specific aetiological agents are scarce, especially from developing countries, because of a lack of means to accurately establish the aetiology [4]. Evidence on seasonality, particularly on the frequency of viral and bacterial causative agents is scarce; such information may be useful in an era of changing climate conditions worldwide.

We aimed to describe the frequency of bacterial and viral infections among children hospitalized for CAP in a tropical region across the seasons of the $y$, analyzing the association between the different aetiological agents and meteorological indicators.

Correspondence: C. M. Nascimento-Carvalho, Paediatrics Department, Federal University of Bahia School of Medicine, Rua Prof. Aristides Novis, No. 105/1201B, Salvador, CEP 40210-630, Bahia, Brazil. Tel:+55 71 32357869. Fax:+55 71 33320725. E-mail: nascimentocarvalho@hotmail.com 


\section{Methods}

\section{Study setting and participants}

This is a subsequent analysis of data collected during a prospective study conducted at the Professor Hosannah de Oliveira Paediatric Centre, Federal University of Bahia, Salvador, in the northeast of Brazil, from September 2003 to May 2005. The latitude and the longitude of Salvador are $12^{\circ} 53^{\prime} 48^{\prime \prime}$ and $38^{\circ} 31^{\prime} 36^{\prime \prime}$, respectively [5].

Patients with respiratory complaints and fever, or difficulty in breathing, had a chest radiograph (CXR) performed at admission. The inclusion criteria included age $<5$ y and radiologically diagnosed pneumonia defined as the presence of a pulmonary infiltrate. A second CXR (2-4 weeks after recruitment) was taken to confirm resolution of pneumonia. A paediatric radiologist blind to clinical information read both CXR.

Initially, 322 consecutive patients were evaluated. Exclusion was due to: refusal to give informed consent $(n=28)$, child born to an HIV-infected woman $(n=6)$, chronic lung disease except asthma $(n=6)$, varicella $(n=3)$, and immunodeficiency $(n=2)$. Pneumonia was confirmed by the paediatric radiologist in 206 patients, of whom 184 had radiological resolution documented; these 184 comprised the study group, assuring the acute course of the studied CAP cases.

The study protocol was approved by the Ethics Committee of the Federal University of Bahia and by the Brazilian National Research Ethics Committee. Informed consent was obtained before enrolment.

\section{Biological samples}

On admission, a blood sample was collected for serologic analysis, reverse transcription-polymerase chain reaction (RT-PCR) search and blood culture; a nasopharyngeal sample was aspirated through a nostril and kept at $-70^{\circ} \mathrm{C}$ until virological tests. A clinical examination was carried out $2-4$ weeks after admission, when the second blood sample for serologic tests was taken.

Viral antigens (influenza A and B viruses, respiratory syncytial virus (RSV), parainfluenza virus types 1, 2, and 3, and adenovirus) in nasopharyngeal aspirates were searched for using a time-resolved fluoroimmunoassay with monoclonal antibodies [6]. Virus-specific serum antibody titres were determined using an enzyme-immunoassay (EIA) [6]. A PCR assay was used for the detection of rhinoviruses [7]. The virological studies were carried out in Turku, Finland.

Antibodies against Streptococcus pneumoniae, non-typable Haemophilus influenzae and Moraxella catarrhalis were measured using an in-house EIA [8]. Chlamydia trachomatis IgG antibodies were detected using a commercial, solid-phase EIA [9]. PCR was used for the detection of S. pneumoniae DNA in blood buffy-coat [10] after extraction of DNA. These bacterial tests were done in Oulu, Finland. IgM antibodies to Mycoplasma pneumoniae were searched for using a commercial EIA kit [11] in Salvador, Brazil.

\section{Meteorological data}

Data on air temperature, relative humidity and precipitation were collected from the Institute of Water Monitoring in the State of Bahia, Brazil (INGA) [5]. Data on air temperature and relative humidity were registered every $3 \mathrm{~h}$, daily and on precipitation were registered once a day. For the purposes of the analysis performed in this study, the month average of air temperature and relative humidity as well as the total precipitation during each month were calculated. The seasons and correspondent months were defined as follows: summer (January, February, March), fall (April, May, June), winter (July, August, September) and spring (October, November, December).

\section{Data analysis}

The distribution of viral, bacterial and any potential pathogen was depicted according to the season. Correlation between the meteorological indicators and the frequency of the aetiologies was assessed by the Pearson or Spearman test, as appropriate. The Pearson Chi-square test was used to compare the proportions among the age groups. The distribution of continuous variables among 4 groups was compared by 1-way analysis of variance (ANOVA) and the groups with significant differences were identified by Turkey. SPSS and STATA (both version 9.0) packages were used for data analysis. The analysis of the frequency of the aetiological agents according to age distribution has been published [12].

\section{Results}

There were 109 (59\%) boys and 75 (41\%) girls, all of them previously healthy. Their median age was 1.6 y (range 26 days-4.9 y). An aetiological agent was found in $144(78 \%)$ of the 184 cases, out of which $43(23 \%)$ were bacterial-viral. Nine viruses were searched for and found at the following frequencies: rhinovirus $(21 \%)$, parainfluenza viruses $(17 \%)$, RSV $(15 \%)$, influenza $\mathrm{A}$ and $\mathrm{B}$ viruses $(9 \%)$, enterovirus $(5 \%)$, adenovirus $(3 \%)$. The detected bacterial pathogens were S. pneumoniae (21\%), H. influenzae ( $8 \%$ ), 
Table I. Meteorological indicators in Salvador, northeast Brazil, during the study on the aetiology of community-acquired pneumonia in hospitalized children.

\begin{tabular}{|c|c|c|c|c|c|c|c|c|c|c|c|c|c|}
\hline \multirow[b]{2}{*}{$\mathrm{Y}$} & \multirow[b]{2}{*}{ Index } & \multicolumn{12}{|c|}{ Month } \\
\hline & & Jan & Feb & Mar & Apr & May & Jun & Jul & Aug & Sep & Oct & Nov & Dec \\
\hline \multirow[t]{3}{*}{2003} & Air temperature $\left({ }^{\circ} \mathrm{C}\right)^{\mathrm{a}}$ & - & - & - & - & - & - & - & - & 24.4 & 25.3 & 26.0 & 25.6 \\
\hline & Relative humidity $(\%)^{\mathrm{a}}$ & - & - & - & - & - & - & - & - & 88.0 & 85.1 & 89.3 & 91.8 \\
\hline & Total precipitation $(\mathrm{mm})$ & - & - & - & - & - & - & - & - & 152.75 & 97.75 & 59.5 & 0 \\
\hline \multirow[t]{3}{*}{2004} & Air temperature $\left({ }^{\circ} \mathrm{C}\right)^{\mathrm{a}}$ & 26.5 & 26.9 & 26.9 & 26.5 & 25.5 & 24.5 & 23.7 & 23.3 & 24.6 & 25.5 & 26.1 & 26.7 \\
\hline & Relative humidity $(\%)^{\mathrm{a}}$ & 90.0 & 87.3 & 88.8 & 89.8 & 92.0 & 93.4 & 88.4 & 93.3 & 86.6 & 89.8 & 89.9 & 88.9 \\
\hline & Total precipitation $(\mathrm{mm})$ & 344.0 & 123.5 & 51.25 & 238.5 & 139.75 & 275.75 & 166.0 & 167.75 & 28.25 & 28.25 & 239.5 & 0.25 \\
\hline \multirow[t]{3}{*}{2005} & Air temperature $\left({ }^{\circ} \mathrm{C}\right)^{\mathrm{a}}$ & 27.0 & 26.7 & 27.2 & 26.1 & 25.5 & - & - & - & - & - & - & - \\
\hline & Relative humidity $(\%)^{\mathrm{a}}$ & 91.8 & 96.4 & 95.1 & 96.0 & 96.8 & - & - & - & - & - & - & - \\
\hline & Total precipitation $(\mathrm{mm})$ & 140.5 & 258.0 & 251.0 & 390.5 & 307.25 & - & - & - & - & - & - & - \\
\hline
\end{tabular}

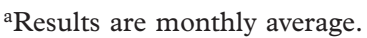

M. pneumoniae (8\%), C. trachomatis (4\%), and M. catarrhalis $(3 \%)$.

During the study period, the median of the month average of relative humidity, air temperature and of total month precipitation were $90 \%$ (mean $91 \% \pm 3 \%$, minimum $85 \%$, maximum $97 \%$ ), $26.0^{\circ} \mathrm{C}$ (mean $26^{\circ} \mathrm{C} \pm 1^{\circ} \mathrm{C}$, minimum $23.3^{\circ} \mathrm{C}$, maximum $27.2^{\circ} \mathrm{C}$ ) and $152 \mathrm{~mm}$ (mean $165 \pm 115 \mathrm{~mm}$, minimum $0 \mathrm{~mm}$, maximum $390 \mathrm{~mm}$ ), respectively. Table I presents the meteorological indicators per month during the study period and Table II presents the comparison of the meteorological indicators among seasons. Significant differences were found in air temperature between spring (October, November, December) and summer (January, February, March) $(p=0.02)$, spring (October, November, December) and winter (July, August, September) $(p<0.001)$, summer (January,
February, March) and fall (April, May, June) ( $p=0.007)$, summer (January, February, March) and winter (July, August, September) $(p<0.001)$, and fall (April, May, June) and winter (July, August, September) $(p=0.002)$ and in precipitation between spring (October, November, December) and fall (April, May, June) $(p=0.01)$. Fall is the rainy season. Overall, $34(18.5 \%), 55(29.9 \%), 39(21.2 \%)$ and $56(30.4 \%)$ CAP cases occurred during the summer (January, February, March), fall (April, May, June), winter (July, August, September) and spring (October, November, December), respectively, and the frequency of detected aetiology was similar between these seasons $(76 \%, 84 \%, 77 \%, 75 \%, p=0.7)$.

Table III presents the distribution of the monthly frequency of the infections detected according to the aetiology established. Table IV shows the assessment

Table II. Comparison of meteorological indicators among seasons during the study on the aetiology of community-acquired pneumonia in hospitalized children, in Salvador, northeast Brazil.

Meteorological indicators

Seasons (number of months included) ${ }^{\mathrm{a}}$

Average relative humidity $(\%) \quad$ Average air temperature $\left({ }^{\circ} \mathrm{C}\right) \quad$ Total precipitation $(\mathrm{mm})$

Spring $(n=6)$

Mean \pm SD

Median

Minimum, maximum

Summer $(n=6)$

Mean \pm SD

Median

Minimum, maximum

Fall $(n=5)$

Mean \pm SD

Median

Minimum, maximum

Winter $(n=4)$

Mean \pm SD

Median

Minimum, maximum

$p$-Value
$89.1 \pm 2.2$
89.6
$85.1-91.8$
$91.6 \pm 3.6$
90.9
87.3-96.4
$93.6 \pm 2.9$
93.4
$89.8-96.8$
$89.1 \pm 2.9$
88.2
$86.6-93.3$
0.08

$25.9 \pm 0.5$
25.8
$25.3-26.7$
$26.9 \pm 0.2$
26.9
$26.5-27.2$
$25.6 \pm 0.8$
25.5
$24.5-26.5$
$24.0 \pm 0.6$
24.0
$23.3-24.6$
$<0.001$

$70.9 \pm 90.7$

43.9

$0-239.5$

$194.7 \pm 107.8$

195.8

$51.2-344.0$

$270.4 \pm 92.1$

275.75

139.75-390.5

$128.7 \pm 67.3$

159.4

28.2-167.8

0.02

a Summer: January, February, March; fall: April, May, June; winter: July, August, September; spring: October, November, December. 
Table III. The distribution of the monthly frequency of infections according to the aetiology detected among hospitalized children with community-acquired pneumonia.

\begin{tabular}{|c|c|c|c|c|c|}
\hline \multirow[b]{2}{*}{ Aetiology } & \multirow[b]{2}{*}{ No. of months } & \multicolumn{4}{|c|}{ Frequency $(\%)$ per month among CAP cases } \\
\hline & & Mean \pm SD & Median & Minimum & Maximum \\
\hline Viral infection & 21 & $61 \pm 15$ & 60 & 38 & 100 \\
\hline Rhinovirus & 17 & $20 \pm 15$ & 18 & 0 & 50 \\
\hline Parainfluenza 1, 2, 3 & 14 & $17 \pm 18$ & 17 & 0 & 50 \\
\hline RSV & 9 & $13 \pm 18$ & 0 & 0 & 54 \\
\hline Influenza A, B & 9 & $11 \pm 23$ & 0 & 0 & 100 \\
\hline Enterovirus & 7 & $4 \pm 7$ & 0 & 0 & 25 \\
\hline Adenovirus & 6 & $5 \pm 12$ & 0 & 0 & 50 \\
\hline Bacterial infection & 20 & $44 \pm 22$ & 46 & 0 & 100 \\
\hline Streptococcus pneumoniae & 17 & $20 \pm 15$ & 20 & 0 & 60 \\
\hline Haemophilus influenzae & 10 & $6 \pm 8$ & 0 & 0 & 25 \\
\hline Mycoplasma pneumoniae & 12 & $12 \pm 22$ & 7 & 0 & 100 \\
\hline Chlamydia trachomatis & 7 & $6 \pm 12$ & 0 & 0 & 50 \\
\hline Moraxella catarrhalis & 5 & $3 \pm 7$ & 0 & 0 & 25 \\
\hline
\end{tabular}

RSV, respiratory syncytial virus.

of correlation between the meteorological indicators and the infections caused by different aetiological agents. Table $\mathrm{V}$ presents the frequency of each aetiological agent per season with the respective statistical analysis. The significant difference for RSV infection was maintained on stratified analysis for age groups $(<1 \mathrm{y}, \geq 1 \mathrm{y},<2 \mathrm{y}, \geq 2 \mathrm{y}$ ) (data not shown). The difference for infection with parainfluenza viruses was significant only for the age group $\geq 2$ y (data not shown).

\section{Discussion}

Marked seasonal patterns of RSV and parainfluenza virus infection are reported in this study. RSV has been recognized as the one of the most frequent aetiological agents responsible for hospitalization in young children, across the globe [13]. In temperate climates, RSV usually occurs during winter (July, August, September) and early spring (October, November, December) [14]. Nonetheless, in Salvador, a tropical city situated in the lower northeast of Brazil, RSV infection peaked in the fall (April, May, June) (Table V). This finding is in accordance with the results of a previous study where children with acute respiratory infection were investigated in Salvador [15] and a recently conducted study in São Paulo, a subtropical city in Brazil [16]. A possible explanation is the circulation of RSV from temperate to tropical regions, during the spring (October,

Table IV. Assessment of correlation between the meteorological indicators and the infections caused by different aetiological agents among children hospitalized with community-acquired pneumonia.

\begin{tabular}{llcc}
\hline & & Meteorological indicators per month \\
\cline { 2 - 4 } Aetiology & Average relative humidity & Average air temperature & Total precipitation \\
\hline Viral infection $^{\mathrm{a}}$ & $0.006^{\mathrm{c}}(0.6)$ & 0.7 & $0.03(0.5)$ \\
Rhinovirus $^{\mathrm{a}}$ & 0.05 & 0.6 & 0.6 \\
Parainfluenza 1, 2, 3 $^{\mathrm{a}}$ & 0.4 & 0.8 & $0.02(-0.5)$ \\
RSV $^{\mathrm{b}}$ & 0.2 & $0.048(-0.4)$ & $0.045(0.4)$ \\
Influenza A, B $^{\mathrm{b}}$ & 0.3 & 0.6 & 0.8 \\
Enterovirus $^{\mathrm{b}}$ & 0.3 & 0.6 & 0.3 \\
Adenovirus $^{\mathrm{b}}$ & 0.1 & 0.6 & $0.02(0.5)$ \\
Bacterial infection $^{\mathrm{a}}$ & 0.3 & 0.7 & 0.8 \\
Streptococcus pneumoniae $^{\mathrm{a}}$ & 0.6 & $0.04(-0.4)$ & 0.7 \\
Haemophilus influenzae $^{\mathrm{b}}$ & 0.9 & 0.6 & 0.4 \\
Mycoplasma pneumoniae $_{\text {Chlamydia trachomatis }}^{\mathrm{b}}$ & 0.06 & 0.3 & 0.09 \\
Moraxella catarrhalis $^{\mathrm{b}}$ & $0.01(-0.5)$ & 0.3 & 0.3 \\
\hline
\end{tabular}

Results are $p$-values ( $r$ in parenthesis when $p$ is significant). RSV, respiratory syncytial virus.

aPearson correlation.

bSpearman correlation.

'Significance at 0.01 level. 
Table V. The frequency of different aetiological agents among hospitalized children with community-acquired pneumonia per season.

\begin{tabular}{|c|c|c|c|c|c|}
\hline \multirow[b]{2}{*}{ Aetiology } & \multicolumn{5}{|c|}{ Seasons ${ }^{\mathrm{a}}$} \\
\hline & Spring $(n=56)$ & Summer $(n=34)$ & Fall $(n=55)$ & Winter $(n=39)$ & $p$-Value \\
\hline Viral infection & $29(51.8)$ & $21(61.8)$ & $37(67.3)$ & $24(61.5)$ & 0.4 \\
\hline Rhinovirus & $9(16.1)$ & $7(20.6)$ & $9(16.4)$ & $13(33.3)$ & 0.2 \\
\hline Parainfluenza $1,2,3$ & $18(32.1)$ & $4(11.8)$ & $4(7.3)$ & $6(15.4)$ & 0.005 \\
\hline RSV & 0 & $1(2.9)$ & $20(36.4)$ & $7(17.9)$ & $<0.001$ \\
\hline Influenza A, B & $4(7.1)$ & $7(20.6)$ & $5(9.1)$ & $1(2.6)$ & 0.06 \\
\hline Enterovirus & $4(7.1)$ & $1(2.9)$ & $5(9.1)$ & 0 & 0.09 \\
\hline Adenovirus & 0 & $2(5.9)$ & $3(5.5)$ & $1(2.6)$ & 0.2 \\
\hline Bacterial infection & $25(44.6)$ & $11(32.4)$ & $25(45.5)$ & $16(41.0)$ & 0.6 \\
\hline Streptococcus pneumoniae & $15(26.8)$ & $4(11.8)$ & $11(20.0)$ & $9(23.1)$ & 0.4 \\
\hline Haemophilus influenzae & $4(7.3)$ & $3(9.1)$ & $6(10.9)$ & $2(5.6)$ & 0.8 \\
\hline Mycoplasma pneumoniae & $3(5.4)$ & $2(5.9)$ & $6(10.9)$ & $3(7.7)$ & 0.7 \\
\hline Chlamydia trachomatis & $3(5.4)$ & $1(2.9)$ & $2(3.6)$ & $3(7.7)$ & 0.8 \\
\hline Moraxella catarrhalis & $2(3.6)$ & 0 & $2(3.6)$ & $1(2.8)$ & 0.5 \\
\hline
\end{tabular}

Results are $n(\%)$. RSV, respiratory syncytial virus.

aSummer: January, February, March; fall: April, May, June; winter: July, August, September; spring: October, November, December.

November, December) (in temperate regions) and fall (April, May, June) (in tropical regions) since they occur concomitantly. The RSV season in Fortaleza, a city in the upper northeast of Brazil, was described to start in the summer (January, February, March) and finish in the winter (July, August, September) [17]. The RSV season is broader in Fortaleza than in Salvador or São Paulo and regional differences should be noticed. A humanized mouse (anti-RSV) monoclonal immune globulin (palivizumab) is recommended as prophylaxis for some high-risk children [18]. Palivizumab must be administered at the beginning of and throughout the RSV season to be effective [18]. Therefore, the recognition of the seasonal pattern of RSV infection in this tropical region is of paramount importance to guide the timing of palivizumab use.

Parainfluenza virus infections peaked in spring (October, November, December) (Table V) among children aged $\geq 2 \mathrm{y}$. The frequency of parainfluenza infection is greatest in preschool-age children [19], and outbreaks usually occur during the fall-winter in temperate climate countries [20]. The marked seasonality observed in parainfluenza infection among toddlers and older children is attributable to the age predominance of this infection. The peak in occurrence during the spring (October, November, December) may be due to the rapid circulation of these viruses because of the great influx of travellers from temperate countries to Salvador during the vacation season. Several respiratory virus epidemics have been described to occur when religious festivals bring large numbers of people into the same area [20]. A similar process occurs in Salvador. Parainfluenza virus has been shown to cause outbreaks in the subtropical city of Rio de Janeiro annually during the late winter (July, August, September) and spring (October, November,
December) [21]. This discrepancy reinforces the necessity of continuous surveillance for respiratory virus infections in large regions.

Rhinovirus, the most commonly detected virus, occurred endemically all y round, peaking in the winter (July, August, September), but without statistical significance (Table V). There is scarce information on the epidemiology of rhinovirus in our country. A previous longitudinal study did not find seasonal predominance of this infection [21] and this report is in accordance with our results. Caution must be taken in interpreting data on rhinovirus infection because of the molecular cross-reactions in the detection of enterovirus and rhinovirus. Nonetheless, we used the more sensitive RT-PCR assay for this diagnosis [7].

Interestingly, despite being a tropical region where variations are narrow in the meteorological indicators, differences were found between the seasons, especially in air temperature (Table II). An inverse correlation could be observed between pneumococcal infections and air temperature (Table IV), i.e., the lower the temperature, the higher the frequency of pneumococcal infection. The wintertime predominance of invasive pneumococcal disease (IPD) has recently been published, being described in Philadelphia, a temperate region where extended periods of low UV radiation were identified as a major predictor of IPD [22]. A population-based study in Taiwan demonstrated that a $1^{\circ} \mathrm{C}$ decrease in ambient temperature was associated with a 0.03 increase in monthly CAP hospitalization [23]. In the latter study, aetiology was not investigated. Nonetheless, as S. pneumoniae is the most common bacterial cause of CAP, it is possible to infer that the association between decreased air temperature and increased CAP hospitalization rate was due to the inverse correlation reported herein. 
We collected data over a 21 -month period with an under-representation of 1 fall month (June) and of 2 winter months (July, August); this is a limitation in our study since some viral infections may switch from an early epidemic peak one y to a late one in the next. Nonetheless, the analysis of the frequencies of infection and the meteorological indicators on a monthly basis overcome this. The correlations found were at regular strength $(r$ 0.3-0.6), which may be attributable to the typical narrow variations in the meteorological indicators in a tropical region.

We provide evidence that even narrow variations in climatic conditions are correlated with the frequencies of distinct causative agents of CAP. This information should be taken into account in the discussions and decision-making regarding the climate in the world.

\section{Acknowledgements}

C. M. Nascimento-Carvalho, M.-R. A. Cardoso and A. Barral are investigators of the Brazilian Council for Science and Technology Development (CNPq). The authors are thankful to the workers of the Institute of Water Monitoring in the State of Bahia, Brazil (INGA) as they provided access to the meteorological data. This study was supported by funding from the Fundação de Amparo à Pesquisa no Estado da Bahia (FAPESB), Salvador, Brazil and the Paediatric Research Foundation, Helsinki, Finland.

\section{Declaration of interest: No conflict of interest.}

\section{References}

[1] McIntosh K. Community-acquired pneumonia in children. N Engl J Med 2002;346:429-37.

[2] Mulholland K. Childhood pneumonia mortality-a permanent global emergency. Lancet 2007;370:285-9.

[3] Scott JA. The global epidemiology of childhood pneumonia 20 years on. Bull World Health Organ 2008;86:494-6.

[4] Scott JA, Brooks WA, Peiris JS, Holtzman D, Mulhollan EK. Pneumonia research to reduce childhood mortality in the developing world. J Clin Invest 2008;118:1291-300.

[5] Institute of Water Monitoring in the State of Bahia, Brazil (INGA). Meteorological indicators in Salvador. Available at: http://sistemas.inga.ba.gov.br/sistemas/planilhas (accessed 4 January 2010).

[6] Mäkelä MJ, Puhakka T, Ruuskanen O, Leinonen M, Saikku $\mathrm{P}$, Kimpimäki M, et al. Viruses and bacteria in the etiology of the common cold. J Clin Microbiol 1998;36:539-42.

[7] Hyypiä T, Puhakka T, Ruuskanen O, Mäkelä M, Arola A, Arstila P. Molecular diagnosis of human rhinovirus infection: comparison with virus isolation. J Clin Microbiol 1998;36: 2081-3.

[8] Nohynek H, Eskola J, Kleemola M, Jalonen E, Saikku P, Leinonen $\mathrm{M}$. Bacterial antibody assays in the diagnosis of acute lower respiratory tract infection in children. Pediatr Infect Dis J 1995;14:478-84.

[9] Morré SA, Munk C, Persson K, Krüger-Kjaer S, van Dijk R, Meijer CJ, et al. Comparison of three commercially available peptide-based immunoglobulin $\mathrm{G}$ (IgG) and IgA assays to microimmunofluorescence assay for detection of Chlamydia trachomatis antibodies. J Clin Microbiol 2002;40:584-7.

[10] Saukkoriipi A, Palmu A, Kilpi T, Leinonen M. Real-time quantitative PCR for the detection of Streptococcus pneumoniae in the middle ear fluid of children with acute otitis media. Mol Cell Probes 2002;16:385-90.

[11] Waris M, Toikka P, Saarinen T, Nikkari S, Meurman O, Vainionpaa $\mathrm{R}$, et al. Diagnosis of Mycoplasma pneumoniae pneumonia in children. J Clin Microbiol 1998;36:3155-9.

[12] Nascimento-Carvalho CM, Ribeiro CT, Cardoso MR, Barral A, Araújo-Neto CA, Oliveira JR, et al. The role of respiratory viral infections among children hospitalized for communityacquired pneumonia in a developing country. Pediatr Infect Dis J 2008;27:939-41.

[13] Ramilo O, Mejías A. Respiratory syncytial virus infections. Old challenges and new strategies. An Pediatr (Barc) 2008; 69:1-4.

[14] Panozzo CA, Fowlkes AL, Anderson LJ. Variation in timing of respiratory syncytial virus outbreaks: lessons from national surveillance. Pediatr Infect Dis J 2007;26:S41-5.

[15] Moura FE, Borges LC, Portes SA, Ramos EA, Siqueira MM. Respiratory syncytial virus infections during an epidemic period in Salvador, Brazil. Viral antigenic group analysis and description of clinical and epidemiological aspects. Mem Inst Oswaldo Cruz 2003;98:739-43.

[16] Thomazelli LM, Vieria S, Leal AL, Sousa TS, Oliveira DB, Golono MA, et al. Surveillance of eight respiratory viruses in clinical samples of pediatric patients in southeast Brazil. J Pediatr (Rio J) 2007;83:422-8.

[17] Moura FE, Nunes IF, Silva GB, Jr, Siqueira MM. Respiratory syncytial virus infections in northeastern Brazil: seasonal trends and general aspects. Am J Trop Med Hyg 2006;74: 165-7.

[18] American Academy of Pediatrics. Respiratory syncytial virus. In: Pickering LK, editor. Red Book 2006. Report of the Committee on Infectious Diseases. 27 $7^{\text {th }}$ ed. Elk Grove Village, IL: American Academy of Pediatrics; 2006. pp. 560-6.

[19] Knott AM, Long CE, Breese C. Parainfluenza viral infections in pediatric outpatients: seasonal patterns and clinical characteristics. Pediatr Infect Dis J 1994;13:269-73.

[20] McIntosh K. Pathogenesis of severe acute respiratory infections in the developing world: respiratory syncytial virus and parainfluenza viruses. Rev Infect Dis 1991;13(Suppl 6): S492-500.

[21] Nascimento JP, Siqueira MM, Sutmoller F, Krawczuk MM, de Farias V, Ferreira V, et al. Longitudinal study of acute respiratory diseases in Rio de Janeiro: occurrence of respiratory viruses during four consecutive years. Rev Inst Med Trop São Paulo 1991;33:287-96.

[22] White AN, NgV, Spain CV, Johnson CC, Kinlin LM, Fisman DN. Let the sun shine in: effects of ultraviolet radiation on invasive pneumococcal disease risk in Philadelphia, Pennsylvania. BMC Infect Dis 2009;9:196.

[23] Lin HC, Lin CC, Chen CS, Lin HC. Seasonality of pneumonia admissions and its association with climate: an eightyear nationwide population-based study. Chronobiol Int 2009;26:1647-59. 